\title{
Model Pengukuran Konstruk Pengetahuan Guru dalam Kemahiran Berfikir Aras Tinggi (KBAT): Analisis Faktor Pengesahan
}

\section{(The Measurement Model of Teacher's Knowledge in Higher Order Thinking Skills (HOTS): A Confirmatory Factor Analysis)}

\author{
Nani Herlin Jamin ${ }^{1 *}$ (D), Shahlan Surat ${ }^{2}$ (D), Wan Muna Ruzanna Wan Mohammad ${ }^{3}$ (D) \\ 1Fakulti Pendidikan, Universiti Kebangsaan Malaysia (UKM), 43600, Bangi, Selangor, Malaysia. \\ Email: nanininja82@gmail.com \\ ${ }^{2}$ Fakulti Pendidikan, Universiti Kebangsaan Malaysia (UKM), 43600, Bangi, Selangor, Malaysia. \\ Email: drshahlan@ukm.edu.my \\ ${ }^{3}$ Fakulti Pendidikan, Universiti Kebangsaan Malaysia (UKM), 43600, Bangi, Selangor, Malaysia. \\ Email: munaruzanna@ukm.edu.my
}

\section{CORRESPONDING \\ AUTHOR (*): \\ Nani Herlin Jamin \\ (nanininja82@gmail.com) \\ KATA KUNCI: \\ Pengetahuan guru \\ Analisis faktor pengesahan \\ Instrumen \\ KEYWORDS: \\ Teacher knowledge \\ Confirmatory factor analysis \\ Instrument \\ CITATION: \\ Nani Herlin Jamin, Shahlan Surat, \& Wan Muna Ruzanna Wan Mohammad. (2022). \\ Model Pengukuran Konstruk Pengetahuan Guru dalam Kemahiran Berfikir Aras Tinggi (KBAT): Analisis Faktor Pengesahan. Malaysian Journal of Social Sciences and Humanities (MJSSH), 7(2), e001299. https://doi.org/10.47405/mjssh.v7i2.1299}

\begin{abstract}
ABSTRAK
Kajian ini bertujuan mengesahkan model pengukuran bagi konstruk pengetahuan guru dalam Kemahiran Berfikir Aras Tinggi (KBAT). 600 orang guru sekolah menengah kerajaan (SMK) Zon Tengah Malaysia dipilih melalui persampelan rawak strata berkadar mengikut negeri iaitu Perak, Selangor, Wilayah Persekutuan Kuala Lumpur dan Putrajaya. Melalui Analisis Faktor Penerokaan (EFA), lima komponen telah dikenal pasti: kualiti perancangan, tindakan perancangan, kualiti pelaksanaan, tindakan pelaksanaan, dan penilaian. Analisis faktor pengesahan (CFA) dilaksanakan menggunakan perisian AMOS versi 24 . Secara keseluruhannya, model pengukuran telah mencapai kesahan konvergen dengan nilai AVE $=0.679$ dan kebolehpercayaan komposit dengan nilai $\mathrm{CR}=0.913$. Model pengukuran lima faktor dengan 39 item ini dicadangkan untuk mengukur pengetahuan guru dalam KBAT.
\end{abstract}

\section{ABSTRACT}

This study aimed to validate the measurement model of teachers 'knowledge in Higher Order Thinking Skills (HOTS). 600 government secondary school teachers in the Central Zone of Malaysia were selected through random sampling of proportional strata by state, namely Perak, Selangor, Federal Territory of Kuala Lumpur and Putrajaya. Through Exploratory Factor Analysis (EFA), five components were identified: planning quality, planning action, implementation quality, implementation action, and evaluation. Confirmation factor analysis (CFA) was performed using AMOS software version 24. Overall, the measurement model has achieved convergent validity with $\mathrm{AVE}=0.679$ and composite reliability with $\mathrm{CR}=0.913$. The five-factor measurement model with 39 items was proposed to measure teachers' knowledge in HOTS. 
Sumbangan/Keaslian: Kajian ini mencadangkan satu bentuk model pengukuran yang baharu bagi mengukur pengetahuan guru dalam KBAT, secara khususnya dalam proses pembelajaran dan pemudahcaraan dengan berasaskan kepada kerangka standard KPM iaitu SKPMg2

\section{Pengenalan}

Elemen kompetensi guru adalah suatu hal yang perlu dikaji kerana kompetensi guru merupakan antara faktor yang menyumbang kepada cabaran dalam pelaksanaan kemahiran berfikir aras tinggi (KBAT) (Abu Bakar \& A. Hamid, 2019). Isnon dan Badusah (2017) menyatakan kompetensi guru merupakan gabungan pengetahuan, kemahiran, pemahaman dan sikap praktik yang ditunjukkan dalam tingkah laku semasa melaksanakan tugas. Ab Halim et al. (2021) menyokong hal ini dengan melihat kompetensi guru berdasarkan Model Iceberg iaitu pengetahuan, kemahiran dan sikap. Dalam kajian ini, kompetensi guru dinyatakan sebagai pengetahuan. Puteh et al. (2012) menyatakan bahawa proses pembelajaran dan pemudahcaraan (PdPc) memerlukan pengetahuan yang cukup agar proses pengembangannya berlaku secara efektif. Dalam konteks kajian, pengetahuan guru dalam PdPc KBAT seharusnya dikuasai terlebih dahulu sebelum PdPc KBAT dapat dilaksanakan dengan berkesan (Schulz \& FitzPatrick 2016) kerana pengetahuan guru dilihat mempunyai hubungan secara langsung dengan amalan PdPc KBAT dalam bilik darjah (Abdullah et al., 2016; Abdul Latir et al., 2014; Hasan \& Mahamod, 2016; Radin Sharuddin \& Mohamad, 2017). Sehubungan dengan itu, guru perlu mempunyai pengetahuan dalam PdPc secara umumnya dan dalam PdPc KBAT khususnya bagi memastikan guru dapat berperanan seperti yang digariskan oleh Kementerian Pendidikan Malaysia (KPM).

KPM telah menggariskan tujuh elemen bagi menjayakan KBAT, iaitu elemen kurikulum, pedagogi dan pentaksiran dibantu dengan elemen sokongan iaitu kokurikulum, bina upaya, sumber serta sokongan komuniti dan swasta (Kementerian Pendidikan Malaysia, 2013). Konteks kajian memberi fokus kepada elemen pedagogi, iaitu PdPc. PdPc KBAT melibatkan tiga proses iaitu perancangan, pelaksanaan dan penilaian (Kementerian Pendidikan Malaysia, 2014; Limbach \& Waugh, 2010; Thomas \& Thorne, 2009). Ini selari dengan penyataan Sang (2011) iaitu perihal pengajaran meliputi aspek perancangan, pelaksanaan dan penilaian yang perlu dilakukan oleh guru. Perancangan bermula sebelum PdPc dapat dilaksanakan dengan mengambil kira semua aspek seperti sukatan pelajaran, kesediaan dan tahap pengetahuan murid, suasana bilik darjah dan bahan sumber pembelajaran yang ada bertujuan memastikan kesediaan dan persediaan yang rapi (Kementerian Pendidikan Malaysia, 2017) sekaligus memberikan keberkesanan dalam melaksanakan PdPc (Othman \& Kassim, 2016). Peringkat perancangan ini seterusnya membawa kepada peringkat pelaksanaan, di mana beberapa bentuk strategi dan pendekatan PdPc KBAT dikenal pasti dapat membantu murid dalam penguasaan KBAT, misalnya melalui teknik penyoalan (Kementerian Pendidikan Malaysia 2014; Saud et al., 2017). Peringkat akhir dalam PdPc KBAT ialah penilaian, iaitu merupakan proses untuk mengesan keberkesanan proses perancangan dan pelaksanaan sekaligus impak kepada keberhasilan murid ke arah KBAT. Pelbagai kaedah penilaian boleh digunakan seperti pentaksiran, menjalankan aktiviti pemulihan/pengayaan, memberi tugasan, membuat refleksi serta menyemak hasil kerja murid berdasarkan objektif pelajaran, mengikut ketetapan pelaksanaan pentaksiran yang berkuat kuasa secara menyeluruh dan berterusan (Kementerian Pendidikan Malaysia, 2017). 
Oleh hal demikian, guru seharusnya menguasai pelaksanaan PdPc KBAT berdasarkan elemen-elemen secara umum, iaitu perancangan, pelaksanaan dan penilaian. Elemenelemen ini telah dinyatakan secara eksplisit melalui instrumen standard sedia ada yang digunakan di Malaysia, iaitu Standard 4 Standard Kualiti Pendidikan Malaysia Gelombang 2 (SKPMg2). KPM telah membina Instrumen Standard Penarafan KBAT dalam PdPc (Penilaian Kendiri Sekolah) pada tahun 2017 berdasarkan standard pembudayaan KBAT dalam PdPc melalui Pelan Perancangan Inisiatif \#20 PPPM: Pembudayaan KBAT Dalam Pembelajaran Abad ke-21. Kedua-dua instrumen ini merupakan instrumen pengukuran standard yang telah dilaksanakan oleh KPM terhadap sekolah-sekolah di Malaysia dalam proses pembudayaan KBAT. Justeru, kandungan dalam kedua-dua instrumen ini dilihat menepati konteks pelaksanaan PdPc KBAT.

Sehingga kini, model pengukuran pengetahuan guru dalam PdPc KBAT berdasarkan kerangka dalam Standard 4 SKPMg2 ini masih belum ada. Bagi Abdul Aziz dan Abd Rahman (2018) guru memerlukan pendedahan tentang konsep KBAT dan cara pengaplikasian KBAT dalam PdPc yang sebetulnya sebagaimana yang dikehendaki oleh KPM. Justeru pengkaji berpendapat satu model pengukuran berkaitan pengetahuan guru dengan berasaskan kerangka Standard 4 SKPMg2 tersebut adalah relevan dengan PdPc KBAT kerana kedua-duanya menepati konsep KBAT dalam sistem pendidikan di Malaysia. Justeru, kajian ini bertujuan untuk mengesahkan instrumen bagi mengukur pengetahuan guru dalam proses PdPc KBAT berdasarkan Standard 4 SKPMg2.

\section{Sorotan Literatur}

\subsection{Pengetahuan Guru}

Pengetahuan guru merupakan bidang kajian yang aktif, sentiasa menjadi perbahasan di kalangan profesional (Bahr \& Mellor, 2016) serta diakui kepentingannya (Desimone, 2009). Pengetahuan guru merupakan asas kebolehan guru dalam PdPc (Hasan \& Mahamod, 2016) serta salah satu kayu pengukur kepada kualiti PdPc yang berkesan (Bahr \& Mellor, 2016; Huling, 2014) dan seterusnya pembelajaran murid (Baumert et al., 2010). Menurut Mat Nor et al. (2018), perkara paling utama dalam perancangan pendidikan ialah kualiti pengetahuan guru. Bagi Jusoh dan Osman (2019) guru berkesan merupakan guru yang berpengetahuan tinggi.

Abdullah et al. (2016) melihat faktor utama yang menjadi penentu kepada kejayaan penyebaran kurikulum ialah ideologi atau pengetahuan penyebar. Guru yang berkualiti diukur melalui pengetahuan yang mendalam terhadap teori PdPc, yang menjadi dasar kepada kefahaman bagaimana murid mempelajari sesuatu perkara (Bahr \& Mellor, 2016). Amalan profesionalisme guru juga diukur berdasarkan pengurusan pengetahuan (David \& Ambotang, 2014). Guru yang menguasai pengetahuan dan kemahiran dapat menyampaikan kandungan sesuai dengan objektif PdPc, menjelaskan konsep/fakta dengan memberi jawapan dengan yakin, jelas dan tepat, menghuraikan isi pelajaran dengan mengaitkannya dengan situasi semasa atau pengalaman murid serta berkemahiran memeringkatkan isi pelajaran mengikut potensi murid (Kementerian Pendidikan Malaysia, 2017). Seseorang guru efektif menurut perspektif pentadbir semestinya mempunyai kecekapan yang mendalam dalam bidang atau subjek yang diajar (Salleh, 2007). Untuk kekal relevan, guru mesti dilengkapi dengan pengetahuan dan kemahiran yang diperlukan agar dapat mencapai apa yang digariskan dalam kurikulum dengan berkesan di dalam bilik darjah (Ab Halim et al., 2021). 
Shulman (1987) menyatakan seorang guru perlu mempunyai tujuh teras pengetahuan iaitu pengetahuan kandungan, pengetahuan pedagogi umum, pengetahuan kurikulum, pengetahuan pedagogi kandungan, pengetahuan tentang murid, pengetahuan konteks pendidikan dan pengetahuan tentang tujuan dan nilai pendidikan. Teras pengetahuan guru yang dikemukakan oleh Shulman (1987) ini telah dijadikan panduan kepada semua kajian berkaitan pengetahuan guru. Hamidon dan Sihes (2021) menghuraikan lima jenis pengetahuan guru, iaitu pengetahuan pedagogi, pengetahuan tentang subjek, kandungan pedagogi, pengetahuan berkaitan murid dan pengetahuan tentang dasar pendidikan, tujuan dan falsafahnya.

Kesimpulannya, pengetahuan guru menjadi salah satu elemen yang mendasari sesuatu amalan, terutama dalam PdPc. Menurut Huling (2014), seseorang guru tidak dapat menyampaikan sesuatu pengetahuan sekiranya mereka sendiri tidak faham konsep pengetahuan tersebut. Apa yang guru tahu mempengaruhi bagaimana mereka mengajar dan apa yang murid belajar (Gess-Newsome, 2015). Bagi membolehkan sesebuah sistem itu berjaya dilaksanakan, pertimbangan pengetahuan dan kemahiran pelaksananya tentang cara melaksanakannya adalah penting. Salah tafsir boleh membawa kepada arahan dan tindakan yang salah di mana ia akan membawa kesan negatif bukan sahaja kepada murid tetapi juga semua orang yang terlibat (Wilson \& Narasuman, 2020).

\subsection{Pengetahuan Guru dalam PdPc KBAT}

Bagi meningkatkan KBAT di kalangan murid adalah penting untuk memahami terlebih dahulu pengetahuan dan kemahiran guru dalam KBAT (Liu \& Roehrig, 2017). Zohar (1999) telah mengemukakan pengetahuan pedagogi yang berkaitan dengan KBAT, yang dirujuk sebagai pengetahuan pedagogi kemahiran berfikir, berdasarkan jenis-jenis pengetahuan guru yang dikemukakan oleh Shulman (1987). Zohar (2013) juga telah mengklasifikasikan pengetahuan untuk mengajar kemahiran berfikir kepada empat, iaitu: 1) Pengetahuan mengenai strategi berfikir individu, seperti membuat perbandingan, membina justifikasi hujah, membuat kesimpulan yang sahih dan lain-lain, 2) Pengetahuan mengenai bentuk berfikir, seperti penghujahan, inkuiri, penyelesaian masalah, pemikiran kritis, pemikiran kreatif, pemikiran saintifik dan lain-lain, 3) Pengetahuan mengenai metakognitif, seperti berfikir tentang cara pemikiran sendiri, 4) Pengetahuan mengenai perkara lain, seperti tabiat minda (habits of mind), budaya berfikir dan sebagainya.

Pengetahuan guru dalam PdPc KBAT didapati berada pada tahap tinggi (Ab Halim et al., 2021; Wan Ismail et al., 2016), sederhana (Abdullah \& Darusalam, 2018; Mohd Radzi \& Muzammil, 2018; Saud et al., 2017) dan lemah (Gunahlan \& Ikhsan, 2018; Pusparini et al., 2020; Zulkpli et al., 2017). Berdasarkan ujian tahap pengetahuan KBAT yang dilaksanakan oleh Zulkpli et al. (2017) menunjukkan hampir separuh daripada guruguru Matematik yang diuji memperoleh skor yang rendah, ekoran daripada kekeliruan guru terhadap istilah dalam KBAT. Guru juga mengaku mereka mempunyai kemahiran pedagogi yang lemah, di mana tidak dapat memilih pendekatan atau kaedah yang dapat meningkatkan penguasaan murid (Singh et al., 2017). Masih ramai guru yang lemah dalam kandungan pengetahuan KBAT menyebabkan pencapaian murid sangat rendah dan sukar untuk mencapai objektif PPPM 2013-2025 (Gunahlan \& Ikhsan, 2018). Hasil kajian kualitatif Pusparini et al. (2020) menunjukkan guru tidak memahami konsep KBAT namun boleh mengaplikasikan KBAT dalam PdPc. Hal ini adalah selari dengan Isnon dan Badusah (2017) yang mendapati tahap pengetahuan guru terhadap KBAT juga berada pada tahap sederhana walaupun mempunyai sikap yang positif terhadap 
pelaksanaan KBAT. Berbeza dengan Wan Ismail et al. (2016) iaitu guru menguasai pengetahuan berkaitan konsep, istilah dan makna KBAT serta positif terhadap pelaksanaan KBAT.

Kajian juga membuktikan terdapat hubungan yang positif dan signifikan antara tahap pengetahuan guru dengan tahap pelaksanaan KBAT dalam bilik darjah (Abdullah et al., 2016; Abdul Latir et al., 2014; Musa \& Meor Samsudin, 2021; Radin Sharuddin \& Mohamad, 2017). Kebanyakan guru yang menguasai pengetahuan KBAT sangat bersetuju bahawa mereka mengaplikasikan Taksonomi Bloom, menitikberatkan cara penyoalan dan penerangan yang melibatkan kemahiran berfikir (Musa \& Meor Samsudin 2021), juga menggunakan pendekatan PdPc KBAT berbentuk kontekstual (Abdul Latir et al., 2014). Dapatan ini selari dengan guru-guru dari aliran Matematik (Abdullah et al., 2016) dan Teknikal (Radin Sharuddin \& Mohamad, 2017). Abdullah et al. (2016) mendapati korelasi kuat yang positif dan signifikan antara tahap pengetahuan dan amalan guru Matematik terhadap pelaksanaan KBAT dalam PdPc. Korelasi yang tinggi dijumpai dalam aspek kurikulum dan pedagogi manakala korelasi lemah pada aspek pentaksiran. Radin Sharuddin dan Mohamad (2017) juga menyokong dapatan ini apabila hubungan sederhana yang positif dan signifikan antara aspek pengetahuan dengan penerapan elemen KBAT dalam pengajaran di dalam bilik darjah di kalangan guru-guru aliran Teknikal.

Kesimpulannya, guru yang berpengetahuan dan berkemahiran yang memupuk tabiat pemikiran dalam kalangan murid mampu menggalakkan muridnya berfikir secara KBAT (Musa \& Meor Samsudin, 2021). Guru perlu mempunyai pengetahuan yang cukup tentang penggunaan aplikasi strategi dan teknik pengajaran supaya amalan PdPc KBAT dapat dilaksanakan dengan berkesan (Abdullah \& Darusalam, 2018; Hasan \& Mahamod, 2016; Saud et al., 2017). Kajian luar negara seperi kajian Baytelman et al. (2020) juga menunjukkan perkaitan antara pengetahuan sesuatu topik dengan kualiti dalam penyampaian topik tersebut. Oleh hal yang demikian, kewajaran dalam mengkaji sejauh mana tahap pengetahuan guru dalam PdPc KBAT memberi kesan ke atas peranan yang dimainkan oleh guru dalam bilik darjah, serta keberhasilan murid KBAT adalah sesuatu yang perlu dititikberatkan.

\subsection{Standard 4 SKPMg2}

Penentuan sesuatu kualiti memerlukan satu set pengukuran yang diguna pakai secara sejagat. Di Malaysia, Standard Kualiti Pendidikan Malaysia (SKPM) telah diperkenalkan pada tahun 2010 sebagai rujukan induk standard kualiti pendidikan yang merangkumi semua aspek berkaitan proses pendidikan dan pengurusan sekolah. SKPM menggunakan rujukan daripada pelbagai standard berkaitan pendidikan terutama berkaitan kepimpinan, pengurusan dan pedagogi (Kementerian Pendidikan Malaysia, 2010) yang digunakan untuk menilai kualiti pendidikan secara berterusan dalam pencapaian bertahap tinggi (Kementerian Pendidikan Malaysia, 2017). Lima standard telah diperkenalkan dalam SKPM 2010 berkaitan kualiti pendidikan sebagai pengukur kepada prestasi sekolah yang berkesan iaitu, Standard 1 bagi Kepimpinan dan Hala Tuju, Standard 2 bagi Pengurusan Organisasi, Standard 3 bagi Pengurusan Kurikulum, Kokurikulum dan Hal Ehwal Murid, Standard 4 bagi Pengajaran dan Pembelajaran, dan Standar 5 bagi Kemenjadian Murid.

Standard 4 merupakan standard yang memberi fokus kepada proses pengajaran dan pembelajaran. Berdasarkan kriteria-kriteria yang dinyatakan dalam standard ini, 
hampir keseluruhan kriteria adalah menjurus kepada elemen guru. Sehubungan itu, elemen guru dalam penentuan kualiti telah diberi fokus dalam semakan semula SKPM pada tahun 2017. Selari dengan pelaksanaan PPPM 2013-2025, SKPM 2010 telah disemak semula dan ditambah baik pada tahun 2017 dengan penjenamaan baharu iaitu SKPMg2. SKPMg2 masih mengekalkan lima standard penilaian yang sama cuma melibatkan pembaharuan dari segi penyataan standard dan kriteria kritikal yang mengandungi subjek, tindakan, kualiti dan impak pelaksanaan. Standard 4 yang pada asalnya ialah pengajaran dan pembelajaran telah diberi penjenamaan semula kepada Pembelajaran dan Pemudahcaraan (PdPc) bersesuaian dengan elemen baharu yang digabungjalinkan iaitu KBAT.

Penyataan Standard 4 merujuk kepada guru berperanan sebagai pemudah cara dalam proses pembelajaran dan pengajaran yang berkesan untuk memperkembangkan potensi murid secara menyeluruh dan meningkatkan pencapaian murid pada tahap optimum secara berterusan (Kementerian Pendidikan Malaysia, 2017). Guru hendaklah melaksanakan pengajaran berpusatkan murid dengan amalan PdPc iaitu guru bertindak sebagai, perancang, pengawal, pembimbing, pendorong dan penilai (Kementerian Pendidikan Malaysia, 2017). Jadual 1 menunjukkan enam aspek dalam Standard 4 SKPMg2 dengan standard kualiti serta tindakan untuk mencapai standard tersebut seperti yang digariskan oleh KPM.

\section{Jadual 1: Enam aspek dalam Standard 4 SKPMg2}

\begin{tabular}{|c|c|c|c|}
\hline Aspek & Subjek & Standard Kualiti & Tindakan untuk Mencapai Standard \\
\hline 4.1 & $\begin{array}{l}\text { Guru Sebagai } \\
\text { Perancang }\end{array}$ & $\begin{array}{l}4.1 \text { Guru } \\
\text { merancang } \\
\text { pelaksanaan PdPc } \\
\text { secara profesional } \\
\text { dan sistematik }\end{array}$ & $\begin{array}{l}\text { Menyediakan RPH, menentukan kaedah } \\
\text { pentaksiran dan menyediakan sumber } \\
\text { pendidikan mengikut keupayaan murid, } \\
\text { peruntukan masa dan mematuhi arahan } \\
\text { yang berkuat kuasa. }\end{array}$ \\
\hline 4.2 & $\begin{array}{l}\text { Guru Sebagai } \\
\text { Pengawal }\end{array}$ & $\begin{array}{l}\text { 4.2.1 Guru } \\
\text { mengawal proses } \\
\text { pembelajaran secara } \\
\text { profesional dan } \\
\text { terancang. } \\
4.2 .2 \text { Guru } \\
\text { mengawal suasana } \\
\text { pembelajaran secara } \\
\text { profesional dan } \\
\text { terancang. }\end{array}$ & $\begin{array}{l}\text { Mengelola isi pelajaran dan peruntukan } \\
\text { masa serta memberi peluang kepada } \\
\text { penyertaan aktif murid dengan menepati } \\
\text { objektif pelajaran, mengikut keupayaan } \\
\text { murid dan secara berterusan dalam PdPc. } \\
\text { Mengawasi komunikasi dan perlakuan } \\
\text { murid, menyusun atur kedudukan murid } \\
\text { dan mewujudkan suasana yang } \\
\text { menyeronokkan mengikut kesesuaian dan } \\
\text { keperluan secara berhemah, menyeluruh } \\
\text { dan berterusan. }\end{array}$ \\
\hline 4.3 & $\begin{array}{l}\text { Guru Sebagai } \\
\text { Pembimbing }\end{array}$ & $\begin{array}{l}\text { 4.3.1 Guru } \\
\text { membimbing murid } \\
\text { secara profesional } \\
\text { dan terancang }\end{array}$ & $\begin{array}{l}\text { Memberi tunjuk ajar dalam menguasai isi } \\
\text { pelajaran dan kemahiran, memandu murid } \\
\text { membuat keputusan dan menyelesaikan } \\
\text { masalah dan menggunakan sumber } \\
\text { pendidikan serta menggabung jalin isi } \\
\text { pelajaran dengan kemahiran/mata } \\
\text { pelajaran lain mengikut keperluan dan } \\
\text { keupayaan murid dengan betul, tepat, } \\
\text { secara berhemah dan bersungguh-sungguh. }\end{array}$ \\
\hline 4.4 & $\begin{array}{l}\text { Guru Sebagai } \\
\text { Pendorong }\end{array}$ & $\begin{array}{l}4.4 .1 \text { Guru } \\
\text { mendorong minda } \\
\text { murid dalam } \\
\text { melaksanakan } \\
\text { aktiviti }\end{array}$ & $\begin{array}{l}\text { Merangsang murid berkomunikasi dan } \\
\text { berkolaboratif, mengemukakan soalan yang } \\
\text { menjurus ke arah pemikiran kritis dan } \\
\text { kreatif untuk membuat keputusan atau } \\
\text { menyelesaikan masalah, mewujudkan }\end{array}$ \\
\hline
\end{tabular}




\begin{tabular}{|c|c|c|c|}
\hline & & $\begin{array}{l}4.4 .2 \text { Guru } \\
\text { mendorong emosi } \\
\text { murid dalam } \\
\text { melaksanakan } \\
\text { aktiviti } \\
\text { pembelajaran secara } \\
\text { profesional dan } \\
\text { terancang. }\end{array}$ & $\begin{array}{l}\text { peluang untuk murid memimpin dan } \\
\text { mengemukakan soalan berkaitan isi } \\
\text { pelajaran serta memperoleh pengetahuan } \\
\text { dan kemahiran secara kendiri berdasarkan } \\
\text { objektif pelajaran, mengikut keupayaan } \\
\text { murid dan secara berterusan. } \\
\text { Memberi pujian, galakan, penghargaan dan } \\
\text { keyakinan serta prihatin terhadap } \\
\text { keperluan murid secara berhemah, } \\
\text { menyeluruh dan berterusan. }\end{array}$ \\
\hline 4.5 & $\begin{array}{l}\text { Guru Sebagai } \\
\text { Penilai }\end{array}$ & $\begin{array}{l}\text { 4.5.1 Guru } \\
\text { melaksanakan } \\
\text { penilaian secara } \\
\text { sistematik dan } \\
\text { terancang. }\end{array}$ & $\begin{array}{l}\text { Menggunakan pelbagai kaedah pentaksiran, } \\
\text { menjalankan aktiviti pemulihan/pengayaan, } \\
\text { memberi tugasan, membuat refleksi serta } \\
\text { menyemak hasil kerja murid berdasarkan } \\
\text { objektif pelajaran, mengikut ketetapan } \\
\text { pelaksanaan pentaksiran yang berkuat } \\
\text { kuasa secara menyeluruh dan berterusan. }\end{array}$ \\
\hline 4.6 & $\begin{array}{l}\text { Murid } \\
\text { Sebagai } \\
\text { Pembelajar } \\
\text { Aktif }\end{array}$ & $\begin{array}{l}\text { 4.6.1 Murid } \\
\text { melibatkan diri } \\
\text { dalam proses } \\
\text { pembelajaran secara } \\
\text { berkesan. }\end{array}$ & $\begin{array}{l}\text { Memberi respons, berkomunikasi dan } \\
\text { melaksanakan aktiviti secara kolaboratif, } \\
\text { berpemikiran kritis dan kreatif, } \\
\text { mengemukakan soalan, menyelesaikan } \\
\text { masalah dan mengaitkan isi pelajaran } \\
\text { dengan kehidupan berdasarkan objektif } \\
\text { pelajaran, secara aktif, yakin dan berhemah. }\end{array}$ \\
\hline
\end{tabular}

Sumber: Kementerian Pendidikan Malaysia (2017)

\subsection{Analisis Faktor Pengesahan}

Analisis faktor pengesahan (CFA) bertujuan menilai hubungan yang wujud antara konstruk dalam model yang dihipotesiskan, dengan melihat, 1) sejauh mana model pengukuran mencapai aras kesepadanan, dan 2) bukti kesahan konstruk yang ditunjukkan oleh model tersebut (Hair et al., 2013). Sekiranya model dilihat menyerupai data sebenar, maka dapat disimpulkan bahawa model hipotesis sepadan dengan data yang diperoleh (Hair et al, 2013). Namun, sekiranya model pengukuran tidak mencapai nilai kesepadanan, maka dapat dirumuskan bahawa kesahan dan kebolehpercayaan sebilangan indikator atau konstruk dalam model tidak boleh diterima dan analisis model struktural tidak dapat diteruskan (Ho, 2013). CFA dilaksanakan untuk menentusahkan kesemua konstruk yang digunakan dalam model. Keperluan utama CFA dilaksanakan adalah (a) teori yang kukuh, (b) model di hipotesis berdasarkan teori tersebut, dan (c) model yang diuji adalah konsisten dengan data yang diperhatikan (Raykov \& Marcoulides, 2006).

Secara teknikal, CFA dapat meminimumkan perbezaan antara matriks kovarians anggaran dengan matriks kovarians tercerap (Schreiber et al., 2006). CFA dijalankan bagi menilai unidimensionaliti, kesahan dan kebolehpercayaan bagi sesuatu konstruk (Awang et al., 2018). CFA dilaksanakan ke atas model hipotesis dalam dua fasa (Hair et al., 2013). Fasa pertama melibatkan penganalisisan kesepadanan model pengukuran bagi setiap konstruk secara berasingan dan fasa kedua melibatkan penganalisisan kesepadanan model secara gabungan bagi kesemua konstruk secara serentak. Kaedah 
ini dilihat lebih berkesan kerana model asal yang kompleks dapat diringkaskan pada fasa pertama dan menjadikan pengukuran pada model gabungan, iaitu fasa kedua menjadi lebih mudah. Tambahan pula, menurut Schreiber et al. (2006) hasil CFA pada fasa pertama adalah lebih parsimoni.

Melalui CFA, anggaran regresi standard yang dihasilkan menunjukkan nilai muatan faktor bagi setiap item dalam model pengukuran. Nilai muatan faktor yang rendah pada sesuatu item menunjukkan item tersebut adalah tidak sepadan dengan model pengukuran dan tidak dapat mengukur konstruk yang berkenaan. Pengekalan item yang mempunyai nilai muatan rendah ini akan menjejaskan indeks kesepadanan model. Oleh sebab itu, item yang mempunyai nilai muatan faktor kurang 0.6 seharusnya digugurkan daripada model kajian. Walau bagaimanapun, sekiranya indeks kesepadanan model tercapai,maka item yang mempunyai nilai muatan faktor rendah ini boleh dikekalkan (Awang et al., 2018). Selain daripada nilai muatan faktor, terdapat beberapa kategori indeks kesepadanan perlu dipatuhi bagi menilai kesepadanan data yang diperoleh dengan model pengukuran.

\section{Metod Kajian}

Populasi kajian terdiri daripada guru-guru SMK di Zon Tengah Malaysia iaitu seramai 53 832 orang (data sehingga 31 Mei 2019), iaitu 26915 orang daripada Selangor, 8371 daripada Wilayah Persekutuan Kuala Lumpur, 828 daripada Wilayah Persekutuan Putrajaya dan 17718 daripada Perak. Populasi ini dipilih kerana ciri-ciri responden dalam populasi kajian adalah menepati konteks kajian, iaitu guru yang terlibat secara langsung dalam pelaksanaan KBAT. Seramai 600 orang responden ditetapkan sebagai sampel kajian dibuat berdasarkan wajaran Krejcie dan Morgan (1970), iaitu pada aras keyakinan 95\% bagi jumlah populasi guru melebihi 100000 sekalipun, jumlah sampel yang diperlukan hanyalah sebanyak 384. Justeru, jumlah 600 sampel untuk kajian ini adalah lebih dari memadai untuk mewakili populasi $(\mathrm{N}=53$ 832). Penambahan ini adalah berdasarkan kepada pandangan Cohen et al. (2011) yang mencadangkan agar kajian yang menggunakan reka bentuk tinjauan memerlukan sampel yang besar. Jumlah sampel juga perlu besar bagi mendapatkan kuasa statistik (Mcleod, 1999).

Pemilihan sampel dalam kajian ini juga dilihat menepati Creswell (2005) yang menjelaskan bahawa semakin besar sampel yang digunakan dalam populasi, semakin rendah potensi ralat sampel yang terdapat dalam populasi. Menurut Hair et al. (2006), penambahan bilangan sampel kajian adalah diperlukan sekiranya, 1) data menunjukkan taburan tidak normal, 2) menggunakan prosedur anggaran alternatif, dan 3) menjangkakan lebih $10 \%$ data hilang. Setelah jumlah sampel ditetapkan, pengkaji memilih sampel dengan teknik pensampelan rawak berstrata berkadaran (proportional stratification sampling approach) bagi memungkinkan sampel yang dipilih mewakili populasi kajian. Di samping itu, teknik pensampelan sebegini juga memudahkan pengkaji menjalankan kajian dan mampu memenuhi matlamat kajian. Kaedah pensampelan rawak berstrata berkadaran ini dicadangkan sebagai satu teknik yang diguna pakai jika bilangan sampel tidak seragam bagi setiap zon (Konting, 1990). Bagi setiap kumpulan strata, peratus kadaran bagi Selangor ialah 49 peratus, Wilayah Persekutuan Kuala Lumpur ialah 16 peratus, Wilayah Persekutuan Putrajaya ialah dua peratus dan Perak ialah 33 peratus. Justeru, bilangan sampel bagi setiap strata ditentukan melalui peratus kadaran terhadap jumlah sampel, iaitu Selangor sebanyak 294 sampel, Wilayah Persekutuan Kuala Lumpur sebanyak 96 sampel, Wilayah Persekutuan Putrajaya sebanyak 12 sampel dan Perak sebanyak 198 sampel. 
Seterusnya, soal selidik mula diadaptasi melalui penghasilan sampel item dengan mengkaji instrumen standard sedia ada, iaitu Standard 4 SKPMg2.Sampel-sampel item diklasifikasikan mengikut tiga komponen yang telah dikenal pasti iaitu perancangan, pelaksanaan dan penilaian. Pengubahsuaian item dari segi struktur ayat dilaksanakan bagi kesesuaian dengan konteks kajian, iaitu pengetahuan guru. Bagi memastikan komponen kandungan dan sampel item yang dibina adalah saling bertepatan, satu Jadual Spesifikasi Item (JSI) telah dibuat seperti yang disarankan oleh Lynn (1986). Secara praktisnya, JSI memudahkan dalam analisis penjajaran bagi sekumpulan item dengan konsep yang membentuk konstruk yang dikaji (Zamanzadeh et al., 2015). Kesemua sampel item diperhalusi dan disusun dalam format dan urutan yang sesuai sehingga membentuk instrumen yang boleh digunakan. Secara keseluruhan, terdapat 63 item telah terhasil, iaitu lapan item dalam komponen perancangan, 38 item dalam komponen pelaksanaan dan 17 item dalam komponen penilaian. Item-item ini disusun dalam bentuk soal selidik dengan skala Likert 5 poin, bermula dari (1) Sangat tidak setuju hingga (5) Sangat Setuju. Skor min yang tinggi menunjukkan tahap pengetahuan yang tinggi, manakala skor min rendah menunjukkan tahap pengetahuan yang rendah.

Dalam kajian ini, kesahan instrumen dimulakan dengan kesahan pakar, yang meliputi kesahan muka dan kesahan kandungan. Berdasarkan kesahan ini, hanya 62 item sahaja diterima daripada keseluruhan 63 item dengan mengekalkan tiga komponen, iaitu perancangan, pelaksanaan dan penilaian. Peringkat seterusnya adalah mendapatkan kesahan konstruk melalui Analisis Faktor Penerokaan (EFA) dan Analisis Faktor Pengesahan (CFA). EFA merupakan langkah pertama pengujian kesahan item sebelum analisis CFA dapat dilaksanakan. EFA dilaksanakan melalui perisian SPSS versi 26 dengan mengambil kira nilai Kaiser-Meyer-Olkin (KMO), nilai muatan faktor, nilai eigenvalue dan putaran Varimax. Nilai muatan faktor yang ditetapkan dalam kajian ialah pada nilai minimum 0.30 (Hair et al., 2006). Dapatan EFA menunjukkan daripada 62 item yang terdiri daripada lapan item bagi sub konstruk perancangan, 37 item bagi sub konstruk pelaksanaan dan 16 item bagi sub konstruk penilaian, hanya 39 item sahaja yang tinggal, iaitu tujuh item bagi sub konstruk perancangan, 21 item bagi sub konstruk pelaksanaan dan 11 item bagi sub konstruk penilaian untuk dibawa ke CFA. Bagi sub konstruk perancangan dan pelaksanaan, masing-masing mempunyai dua komponen, manakala bagi sub konstruk penilaian, mempunyai satu komponen. Komponenkomponen ini telah dinamakan sebagai (1) kualiti perancangan (PRK), (2) tindakan perancangan (PRT), (3) kualiti pelaksanaan (PLK), (4) tindakan pelaksanaan (PLT) dan (5) penilaian (PN). Model pengukuran yang dicadangkan adalah seperti dalam Rajah 1.

CFA dikendalikan ke atas model pengukuran berdasarkan faktor yang dihipotesiskan menggunakan perisian Analysis of Moment Structure (AMOS) versi 24. Terdapat tiga jenis kesahan yang dilaksanakan semasa ujian CFA, iaitu kesahan konvergen, kesahan konstruk dan kesahan diskriminan. Kesahan konstruk dicapai apabila indeks kesepadanan konstruk mencapai tahap yang diperlukan. Untuk memeriksa kesepadanan model pengukuran maka indeks kesepadanan seperti: (i) nilai minimum bagi perbezaan antara data yang diperhatikan dan model yang dihipotesiskan dibahagikan dengan darjah kebebasan (Chi-square/df), (ii) Comparative of Fit Index (CFI), (iii) Indeks TuckerLewis (TLI), dan (iv) The Root Mean Square Error of Approximation (RMSEA) diperiksa. Jadual 2 menunjukkan aras penerimaan indeks bagi empat nilai seperti yang dinyatakan mengikut indeks kesepadanan. 
Rajah 1: Model Pengukuran Konstruk Pengetahuan Guru

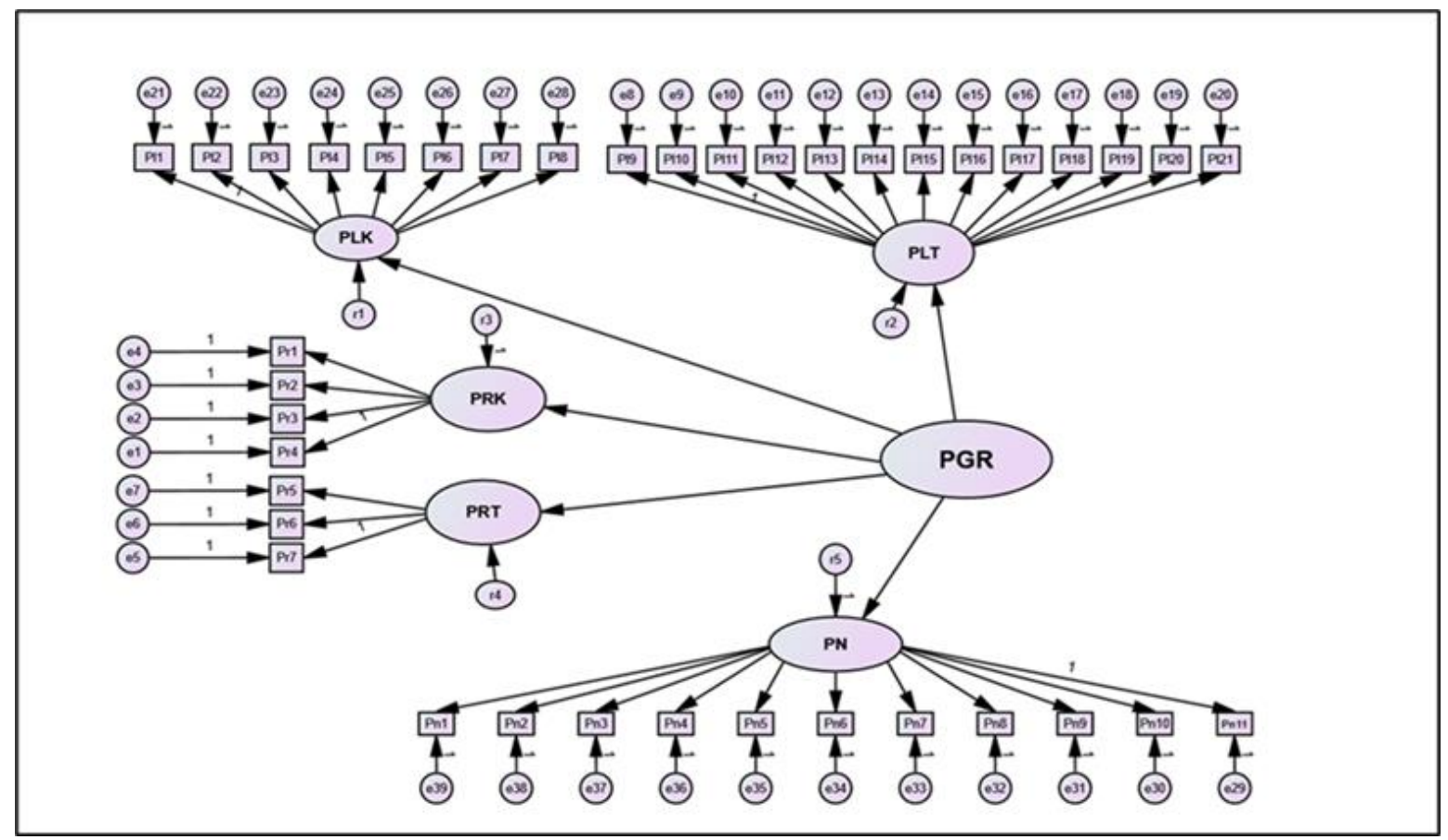

Jadual 2: Aras Penerimaan Indeks Kesepadanan

\begin{tabular}{ll}
\hline Nama Indeks & Aras Penerimaan \\
\hline RMSEA & $\leq 0.1$ boleh diterima (terbaik jika nilai 0.08) \\
TLI & $>0.90($ CLI $>0.85$ masih diterima jika model kompleks) \\
CFI & $>0.90$ (CLI $>0.85$ masih diterima jika model kompleks) \\
Chi-square $/ d f$ & $<5$ (ideal jika nilai $<3.0)$
\end{tabular}

Sumber: Awang et al. (2018)

Seterusnya pengesahan model pengukuran turut melibatkan kesahan konvergen dan kesahan diskriminan. Kesahan konvergen merujuk kepada pengukuran konsep yang sama dengan kadar perkongsian varians yang tinggi (Hair et al., 2013). Bagi Pallant (2016) kesahan konvergen dikatakan tercapai apabila kesemua item dalam model pengukuran adalah signifikan secara statistik dan mempunyai ketekalan dalaman. Nilai AVE dihitung bagi setiap konstruk dan perlu mencapai sekurang-kurangnya 0.50 bagi menentusahkan kesahan menumpu. Mana-mana konstruk yang tidak mencapai nilai AVE sekurang-kurangnya 0.50 menunjukkan terdapat item dalam konstruk berkenaan yang dikekalkan walaupun mempunyai muatan faktor rendah. Kesahan diskriminan menunjukkan sejauh mana model pengukuran sesuatu konstruk itu bebas daripada item bertindih, yang boleh dikenal pasti melalui nilai MI (Awang et al., 2018). Nilai MI yang tinggi dari 15 menunjukkan terdapat item bertindih yang perlu disingkirkan salah satu item atau mengekang pasangan item yang berulang. Kesahan diskriminan juga dicapai apabila korelasi antara konstruk eksogenus tidak melebihi 0.85. Nilai korelasi antara konstruk yang melebihi 0.85 menunjukkan model mempunyai masalah multikolineariti yang serius.

Kebolehpercayaan dalam model pengukuran menilai sejauh mana model pengukuran tersebut konsisten dalam mengukur konstruk yang berkaitan (Awang et al., 2018). Terdapat dua kriteria kebolehpercayaan yng digunakan iaitu CR dan AVE. Nilai CR > 
0.60 dan AVE > 0.50, masing-masing menunjukkan kebolehpercayaan bagi konstruk tersebut telah tercapai. Namun begitu, terdapat juga konstruk yang tidak mencapai nilai AVE sekurang-kurangnya 0.50 walaupun kesemua item mempunyai muatan faktor melebihi 0.60. Dalam hal ini Fornell dan Larcker (1981) menyatakan sekiranya nilai AVE kurang daripada 0.50 tetapi nilai kebolehpercayaan komposit melebihi 0.60 , maka kesahan konvergen bagi konstruk berkenaan masih diterima.

\section{Hasil Kajian}

\subsection{Analisis Faktor Pengesahan(CFA)}

Sebelum melaksanakan CFA konstruk aras kedua, pengkaji terlebih dahulu menjalankan CFA konstruk aras pertama bagi memastikan kesemua sub konstruk adalah bebas dan saling tidak bertindih melalui nilai korelasi sesama sub konstruk. Nilai korelasi sesama sub konstruk melebihi 0.85 menunjukkan berlaku pertindihan antara sub konstruk (Awang, 2016) dan kesahan diskriminan tidak dapat dicapai (Fornell \& Lacker, 1981). Berdasarkan Rajah 2 kesemua korelasi antara sub konstruk adalah kurang daripada 0.85 , iaitu 0.758, 0.721, 0.581, 0.744, 0.524, 0.791, 0.442, 0.720, 0.797, 0.662. Ini membuktikan bahawa kesemua lima sub konstruk yang mengukur pengetahuan guru (PGT) adalah tidak bertindih dan telah mencapai kesahan diskriminan serta tiada isu multikolineariti (Hair et al., 2013).

\section{Rajah 2: Dapatan CFA aras pertama}

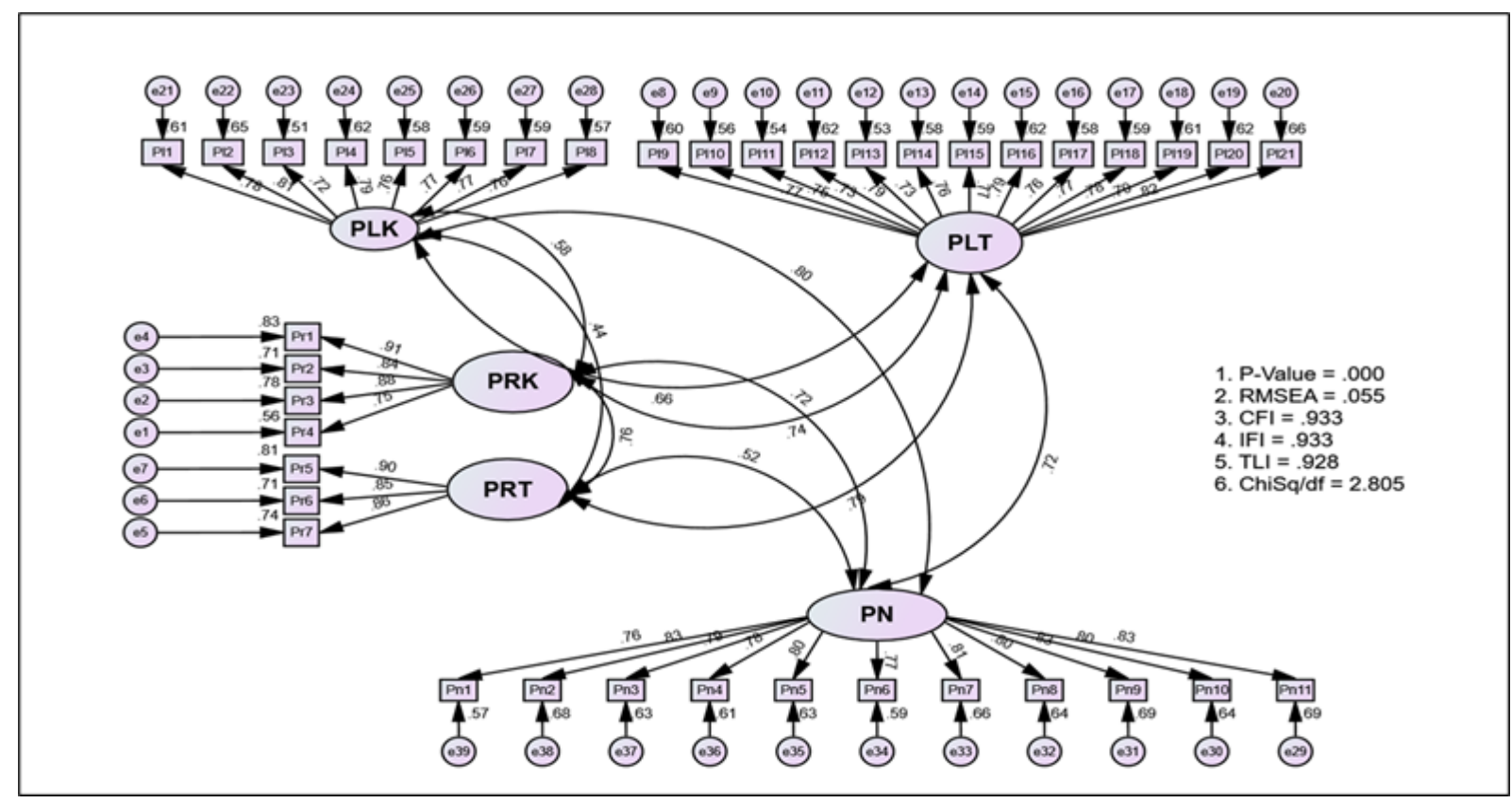

Seterusnya, pengkaji melaksanakan CFA aras kedua bagi model pengukuran konstruk pengetahuan guru. Dapatan CFA aras kedua dalam Rajah 3 menunjukkan nilai indeks kesepadanan telah mencapai aras penerimaan, iaitu nilai RMSEA $=0.61, \mathrm{CFI}=0.918$, TLI $=0.913 \mathrm{dan}$ Chisq $/ \mathrm{df}=3.175$.

Model pengukuran akhir konstruk pengetahuan guru telah mencapai kesemua nilai indeks kesepadanan serta kesemua item dan komponen mempunyai muatan faktor > 0.60. Ini menunjukkan model pengukuran ini telah mencapai keekadimensian dan kesahan konstruk. Seterusnya nilai kesahan konvergen diperoleh melalui nilai AVE iaitu 
$>0.50$ dan penilaian kebolehpercayaan bagi model pengukuran konstruk melalui nilai $\mathrm{CR}$, iaitu $>$ 0.60. Kesemua dapatan nilai kesahan dan kebolehpercayaan ini ditunjukkan dalam Jadual 3.

Rajah 3: Dapatan CFA aras kedua

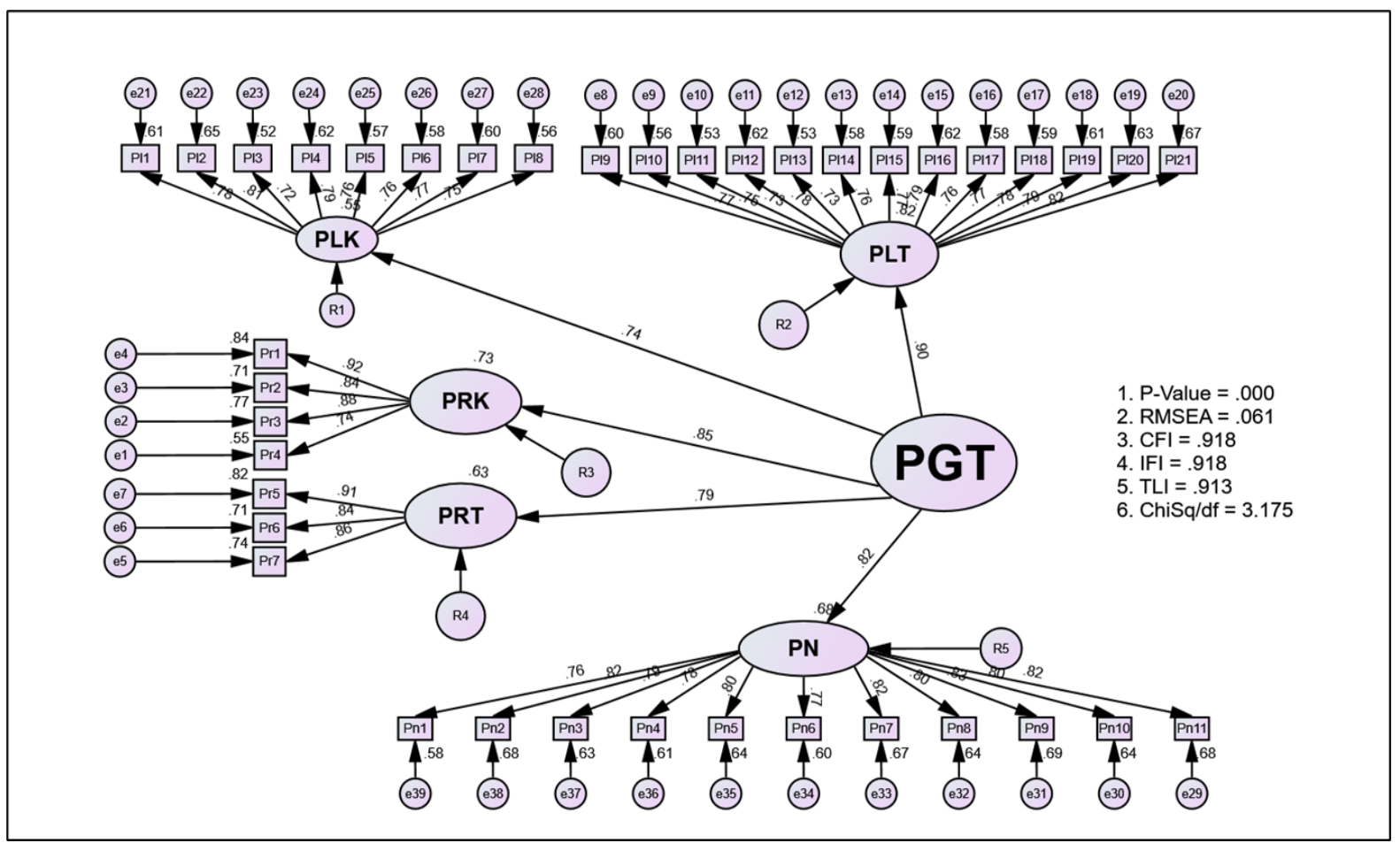

Jadual 3: Nilai kesahan dan kebolehpercayaan model pengukuran konstruk pengetahuan

\begin{tabular}{|c|c|c|c|c|}
\hline Konstruk & Sub konstruk & Muatan Faktor & CR $(>0.60)$ & $\operatorname{AVE}(>0.50)$ \\
\hline \multirow[t]{5}{*}{ PGT } & PRK & 0.852 & 0.913 & 0.679 \\
\hline & PRT & 0.792 & & \\
\hline & PLK & 0.743 & & \\
\hline & PLT & 0.903 & & \\
\hline & PN & 0.822 & & \\
\hline Sub Konstruk & Item & & & \\
\hline \multirow[t]{4}{*}{ PRK } & Pr1 & 0.919 & 0.910 & 0.719 \\
\hline & Pr2 & 0.841 & & \\
\hline & Pr3 & 0.877 & & \\
\hline & Pr4 & 0.744 & & \\
\hline \multirow[t]{3}{*}{ PRT } & $\operatorname{Pr} 5$ & 0.906 & 0.902 & 0.755 \\
\hline & Pr6 & 0.840 & & \\
\hline & Pr7 & 0.859 & & \\
\hline \multirow[t]{10}{*}{ PLK } & Pl1 & 0.784 & 0.920 & 0.590 \\
\hline & $\mathrm{Pl} 2$ & 0.806 & & \\
\hline & $\mathrm{Pl} 3$ & 0.721 & & \\
\hline & $\mathrm{Pl} 4$ & 0.787 & & \\
\hline & $\mathrm{Pl} 5$ & 0.755 & & \\
\hline & $\mathrm{Pl} 6$ & 0.764 & & \\
\hline & $\mathrm{Pl} 7$ & 0.774 & & \\
\hline & $\mathrm{Pl} 8$ & 0.749 & & \\
\hline & Pl10 & 0.750 & & \\
\hline & Pl11 & 0.731 & & \\
\hline
\end{tabular}




\begin{tabular}{lll} 
Pl12 & 0.784 \\
Pl13 & 0.726 \\
Pl14 & 0.763 \\
Pl15 & 0.768 \\
Pl16 & 0.788 \\
Pl17 & 0.762 & \\
Pl18 & 0.768 & \\
Pl19 & 0.782 & \\
Pl20 & 0.792 & \\
Pl21 & 0.816 & \\
Pn1 & 0.759 & \\
Pn2 & 0.825 & \\
Pn3 & 0.792 & \\
Pn4 & 0.782 & \\
Pn5 & 0.799 & \\
Pn6 & 0.772 & \\
Pn7 & 0.816 & \\
Pn8 & 0.798 \\
Pn9 & 0.831 & \\
Pn10 & 0.800 & \\
Pn11 & 0.824 & \\
\hline
\end{tabular}

Secara keseluruhan, model pengukuran konstruk pengetahuan guru dilihat telah mencapai kesahan konvergen dengan nilai $\mathrm{AVE}=0.679$, dan kebolehpercayaan komposit dengan nilai $\mathrm{CR}=0.913$. Kesemua sub konstruk juga telah mencapai kesahan konvergen dan kebolehpercayaan, dengan nilai AVE $>0.50$ dan nilai CR $>0.60$.

\section{Perbincangan Kajian}

Dapatan EFA telah menghasilkan 39 item dengan lima sub konstruk, iaitu kualiti perancangan, tindakan perancangan, kualiti pelaksanaan, tindakan pelaksanaan dan penilaian telah dapat dihasilkan. Dapatan CFA aras pertama menunjukkan kelima-lima sub konstruk tersebut tidak mempunyai masalah multikolineariti. Ini menunjukkan kesemua sub konstruk adalah saling eksklusif antara satu sama lain. Dapatan kajian juga menunjukkan model pengukuran ini telah memenuhi semua syarat kebolehpercayaan serta tiga jenis kesahan, iaitu kesahan diskriminan, kesahan menumpu dan kesahan konstruk.

Oleh hal demikian, kajian ini menunjukkan terdapat kesepadanan model pengukuran pengetahuan guru dalam PdPc KBAT dengan data kajian yang diperoleh. Keputusan ini adalah selari dengan pemahaman pengkaji terhadap pengetahuan guru dalam PdPc KBAT berdasarkan tiga proses dalam PdPc KBAT yang dikemukakan oleh Kementerian Pendidikan Malaysia (2014), Limbach dan Waugh (2010) serta Thomas dan Thorne (2009) iaitu perancangan, pelaksanaan dan penilaian serta aspek kualiti dan tindakan seperti yang disarankan dalam SKPMg2.

Kebanyakan kajian-kajian lepas mengukur tahap pengetahuan guru dalam PdPc KBAT secara umum tanpa pembahagian aspek yang jelas, dan lebih menjurus kepada pelaksanaan KBAT secara umum. Misalnya, dalam kajian Wan Jaafar dan Abdul Razak (2021) dilihat hanya terdapat tiga item sahaja dalam aspek perancangan daripada keseluruhan 10 buah item, dan hanya satu item dalam aspek penilaian daripada keseluruhan 10 item dalam Hasan dan Mahamod (2016), Isnon dan Badusah (2017), Zainal Abidin dan Osman (2017) dan Zaki et al. (2021). Mohd Radzi dan Muzammil 
(2018) mengukur pengetahuan guru dengan hanya tiga item dalam aspek perancangan dan satu item dalam aspek penilaian. Begitu juga Ramasamy (2016), iaitu masingmasing hanya satu item bagi aspek perancangan dan penilaian.

Namun begitu, terdapat juga kajian yang melihat pengetahuan guru dalam PdPc KBAT mengikut konstruk-konstruk tertentu, misalnya Jusoh dan Osman (2019) mengukur pengetahuan guru dalam PdPc KBAT melalui empat sub konstruk, iaitu pengetahuan asas KBAT, pengetahuan pedagogi Sains berasaskan KBAT, pengetahuan pembinaan item elemen KBAT dan pengetahuan pentaksiran. Abdullah et al. (2016) mengukur pengetahuan guru dalam PdPc KBAT dari aspek kurikulum, pedagogi dan penilaian. Selain itu, terdapat kajian mengukur kepada dua sub konstruk iaitu sebelum dan semasa PdPc (Mat Isa \& Mahamod, 2021) dan satu konstruk sahaja iaitu pentaksiran KBAT (Shammugam \& Sihes 2014), pedagogi KBAT (Tay et al., 2017), konsep Bloom (Wan Ismail et al., 2016) dan aspek Pentaksiran Berasaskan Sekolah (Wilson \& Narasuman, 2020).

Model pengukuran pengetahuan guru dalam PdPc KBAT ini merupakan satu bentuk model cadangan baharu kerana sehingga kini, tiada lagi kajian yang mengukur pengetahuan guru dalam PdPc KBAT berdasarkan Kerangka Pedagogi KBAT KPM yang dikeluarkan pada tahun 2014 dan digabungjalinkan dengan kandungan dalam Standard 4 SKPMg2 yang dikeluarkan pada tahun 2017. Bagi Abdul Aziz dan Abd Rahman (2018) guru memerlukan pendedahan tentang konsep KBAT dan cara pengaplikasian KBAT dalam PdPc yang sebetulnya sebagaimana yang dikehendaki oleh KPM. Justeru pengkaji berpendapat bahawa kedua-dua konsep kandungan tersebut adalah relevan dengan PdPc KBAT kerana kedua-duanya menepati konsep KBAT dalam sistem pendidikan di Malaysia.

Dengan memperkenalkan tiga sub konstruk pada asalnya, iaitu perancangan, pelaksanaan dan penilaian (seperti dalam Kerangka Pedagogi KBAT KPM), telah bercambah kepada lima sub konstruk, kualiti perancangan, tindakan perancangan, kualiti pelaksanaan, tindakan pelaksanaan dan penilaian (gabungjalin dengan SKPMg2) berdasarkan dapatan EFA, seterusnya disahkan melalui CFA telah berjaya mengukur konsep pengetahuan guru dalam PdPc KBAT seperti yang dimaksudkan dengan tepat. Walau bagaimanapun, pengukuran tersebut hanya terhad kepada guru-guru SMK di Zon Tengah sahaja. Sehubungan itu, pengkaji lain boleh mengadaptasi model pengukuran ini mengikut konteks dan kehendak kajian masing-masing.

\section{Kesimpulan}

Kesimpulannya, guru seharusnya melengkapkan diri dengan pengetahuan berkaitan KBAT, terutama dalam PdPc bukan sahaja untuk mencapai skor standard yang ditetapkan oleh KPM, malah memberi impak yang jauh lebih bermakna iaitu keberhasilan murid sebagai pembelajaran aktif, khususnya ke arah KBAT. Sehubungan itu, sejauh mana guru memiliki pengetahuan terhadap setiap fasa adalah penting bagi memastikan objektif PdPc KBAT tersebut berkesan. Dalam pelaksanaan KBAT, pengetahuan mengenai penerapan KBAT dalam proses PdPc wajar difahami dan diamalkan oleh semua guru kerana hanya guru yang mampu mempelbagaikan kaedah pengajaran akan berjaya mencapai cita-cita untuk melahirkan murid KBAT (David \& Ambotang, 2014). 


\section{Penghargaan (Acknowledgement)}

Terima kasih kepada pakar-pakar yang terlibat sebagai penasihat dalam mendapatkan maklumat berkaitan, terutama daripada Jemaah Nazir dan Jaminan Kualiti, Kementerian Pendidikan Malaysia serta semua pentadbir sekolah terlibat dalam memberi kebenaran melaksanakan kajian. Penghargaan ditujukan juga kepada semua guru yang terlibat dalam kajian ini.

\section{Kewangan (Funding)}

Kajian ini merupakan hasil dapatan penulisan tesis penulis yang mendapat tajaan Hadiah Latihan Persekutuan Sambilan Peringkat Kedoktoran daripada Kementerian Pendidikan Malaysia.

\section{Konflik Kepentingan (Conflict of Interests)}

Penulis tidak mempunyai konflik kepentingan dengan mana-mana pihak dan kajian ini hanya berbentuk ilmiah sahaja.

\section{Rujukan}

Ab Halim, A. S., Osman, K., Aziz, M. S. A. M., Ibrahim, M. F., \& Ahmad, A. A. K. (2021). The Competency of Science Teachers in Integrating Higher Order Thinking Skills in Teaching and Learning. Journal of Physics: Conference Series, 1793(1).

Abdul Aziz, F. A., \& Abd Rahman, F. (2018). Sorotan Kajian Kesediaan Dan Keperluan Guru Bahasa Melayu Dalam Pelaksanaan Kemahiran Berfikir Aras Tinggi (KBAT) Di Bilik Darjah. Pendeta Journal of Malay Language, Education and Literature, 9, 80-101.

Abdul Latir, S. S., Hamzah, R., \& Mat Rashid, A. (2014). Hubungan pengetahuan dan sikap guru sains pertanian terhadap pengajaran konstekstual. Sains Humanika, 2(4), 1-5.

Abdullah, A. H., Mokhtar, M., Abd Halim, N. D., Ali, D. F., Mohd Tahir, L., \& Abdul Kohar, U. H. (2016). Mathematics Teachers' Level of Knowledge and Practice on the Implementation of Higher-Order Thinking Skills (HOTS). EURASIA Journal of Mathematics, Science and Technology Education, 13(1).

Abdullah, N. H. H., \& Darusalam, G. (2018). Kesediaan guru melaksanakan kemahiran berfikir aras tinggi dalam pengajaran. Jurnal Kurikulum \& Pengajaran Asia Pasifik, 6(3), 22-31.

Abu Bakar, A. Y., \& A. Hamid, A. H. (2019). Issues and challenges in implementing high order thinking skills (HOTS) in schools: The Malaysian perspective. International Journal of Management and Applied Science, 5(6), 55-60.

Awang, Z. (2016). SEM Made Simple: A Gentle Approach to Learning Structural Equation Modelling. Bandar Baru Bangi: MPWS Rich Publications.

Awang, Z., Lim, S. H., \& Zainudin, N. F. S. (2018). Pendekatan Mudah SEM Structural Equation Modelling. MPWS Rich Publications.

Bahr, N. M., \& Mellor, S. (2016). Building Quality in Teaching and Teacher Education. Australian Council for Educational Research.

Baumert, J., Kunter, M., Blum, W., Brunner, M., Voss, T., Jordan, A., Klusmann, U., Krauss, S., Neubrand, M., \& Tsai, Y. M. (2010). Teachers' Mathematical Knowledge, Cognitive Activation in the Classroom, and Student Progress. American Educational Research Journal, 47(1), 133-180. 
Baytelman, A., Iordanou, K., \& Constantinou, C. P. (2020). Epistemic beliefs and prior knowledge as predictors of the construction of different types of arguments on socioscientific issues. Journal of Research in Science Teaching, 57(8), 1199-1227.

Cohen, L., Manion, L., \& Morrison, K. R. B. (2011). Research Methods in Education. Routledge.

Creswell, J. W. (2005). Educational Research: Planning, Conducting, and Evaluating Quantitative and Qualitative Research (2nd Edition) (2nd ed.). Prentice Hall.

David, C., \& Ambotang, A. S. (2014). Profesionalisme Guru Novis dalam Pengurusan Pengetahuan, Kesediaan Mengajar dan Kemahiran Berfikir Aras Tinggi (KBAT) Terhadap Pelaksanaan Pengajaran di Sekolah. Seminar Kebangsaan Integriti Keluarga 2014, Sabah, Malaysia.

Desimone, L. M. (2009). Improving Impact Studies of Teachers' Professional Development: Toward Better Conceptualizations and Measures. Educational Researcher, 38(3), 181-199.

Fornell, C., \& Larcker, D. F. (1981). Evaluating Structural Equation Models with Unobservable Variables and Measurement Error. Journal of Marketing Research, 18(1), 39.

Gess-Newsome, J. (2015). A model of teacher professional knowledge and skill including PCK: Results of the thinking from the PCK Summit. In Re-examining pedagogical content knowledge in science education. (pp. 38-52). Routledge.

Gunahlan, V. M., \& Ikhsan, Z. (2018). Mastering the Basic Content Knowledge in Higher Order Thinking Skills Among Teachers in Malaysia in Teaching and Learning Process. Proceeding of the 2nd URICES. Pekanbaru, Indonesia.

Hair, J., Black, W., Babin, B., Anderson, R., \& Tatham, R. (2006). Multivariate Data Analysis (6th ed.). Upper Saddle River, NJ: Pearson Prentice Hall.

Hair, J. F., Black, W. C., Babin, B. J., \& Anderson, R. E. (2013). Multivariate Data Analysis. Pearson Education Limited.

Ho, R. (2013). Handbook of Univariate and Multivariate Data Analysis with IBM SPSS (2nd ed.). Chapman and Hall/CRC.

Hamidon, M., \& Sihes, A. J. (2021). Influence of Islamic Education Teachers Competency on Practice of Higher Order Thinking Skills. International Journal of Academic Research in Progressive Education and Development, 9(2), 815-830.

Hasan, N. H., \& Mahamod, Z. (2016). Persepsi guru bahasa Melayu sekolah menengah terhadap kemahiran berfikir aras tinggi. Jurnal Pendidikan Bahasa Melayu, 6(2), 78-90.

Huling, M. D. (2014). The effect of teachers' epistemological beliefs on practice (Thesis). University of South Florida. https://digitalcommons.usf.edu/etd/5044

Isnon, H., \& Badusah, J. (2017). Kompetensi guru Bahasa Melayu dalam menerapkan kemahiran berfikir aras tinggi dalam pengajaran dan pembelajaran. Jurnal Pendidikan Bahasa Melayu, 7(1), 56-65.

Jusoh, N., \& Osman, K. (2019). Tahap kesediaan dan keperluan latihan guru dalam mengaplikasikan KBAT dalam PdPc Sains. International Journal of Modern Trends in Social Sciences, 42-54.

Kementerian Pendidikan Malaysia. (2010). Standard Kualiti Pendidikan Malaysia. Jemaah Nazir dan Jaminan Kualiti.

Kementerian Pendidikan Malaysia. (2013). KBAT Inisiatif Kemahiran Berfikir Aras Tinggi di Sekolah. Bahagian Pembangunan Kurikulum.

Kementerian Pendidikan Malaysia. (2014). Elemen KBAT dalam pedagogi. Bahagian Pembangunan Kurikulum.

Kementerian Pendidikan Malaysia. (2017). Standard Kualiti Pendidikan Malaysia Gelombang 2 SKPMg2. Jemaah Nazir dan Jaminan Kualiti. 
Konting, M. M. (1990). Kaedah penyelidikan pendidikan. Dewan Bahasa dan Pustaka.

Krejcie, R. V., \& Morgan, D. W. (1970). Determining Sample Size for Research Activities. Educational and Psychological Measurement, 30(3), 607-610.

Limbach, B., \& Waugh, W. (2010). Developing higher level thinking. Journal of Instructional Pedagogies, 3.

Liu, S., \& Roehrig, G. (2017). Exploring Science Teachers' Argumentation and Personal Epistemology About Global Climate Change. Research in Science Education, 49(1), 173-189.

Lynn, M. R. (1986). Determination and Quantification Of Content Validity. Nursing Research, 35(6), 382-386.

Mat Isa, N. S., \& Mahamod, Z. (2021). Tahap pengetahuan, sikap dan masalah guru bahasa melayu terhadap penerapan kemahiran berfikir aras tinggi dalam pengajaran dan pembelajaran KOMSAS. Asian People Journal (APJ), 4(1), 93-107.

Mat Nor, M. N. A., Kamarudin, N., Abdul Manaf, U. K., \& Mohd Puad, M. H. (2018). Persepsi Guru Terhadap Pengaplikasian Kemahiran Berfikir Aras Tinggi (KBAT) dalam Reka Bentuk dan Teknologi (RBT) Sekolah Rendah. International Journal of Education and Training (InjET), 4(2), 1-8.

McLeod, J. (1999). Melaksanakan penyelidikan kaunseling. Universiti Teknologi Malaysia. Mohd Radzi, N., \& Muzammil, N. F. (2018). Tahap kompetensi guru dalam pelaksanaan kemahiran berfikir aras tinggi di sekolah kebangsaan daerah Sepang, Selangor. Jurnal Kurikulum \& Pengajaran Asia Pasifik, 6(4), 12-28.

Musa, M., \& Meor Samsudin, W. N. A. (2021). Implementasi Kemahiran Berfikir Aras Tinggi (KBAT) Matematik: Adakah Suatu Realiti? Sains Malaysiana, 50(9), 27812790.

Othman, M. S., \& Kassim, A. Y. (2016). Keberkesanan permulaan pengajaran menerusi amalan Kemahiran Berfikir Aras Tinggi (KBAT) di dalam mata pelajaran Pendidikan Islam sekolah rendah negeri Perak. Online Journal of Islamic Education, $4(2), 23-35$.

Pallant, J. (2016). SPSS Survival Manual: A Step by Step Guide to Data Analysis Using SPSS Program (6th ed.). London, UK: McGraw-Hill Education.

Pusparini, D., Suparno, S., \& Sarosa, T. (2020). Teachers' Knowledge about Higher-order Thinking Skill and It's Implementation in Teaching Reading Classroom: A Case Study in a Higher Secondary School in Indonesia. Edulingua: Jurnal Linguistiks Terapan Dan Pendidikan Bahasa Inggris, 7(2), 75-84.

Puteh, S. N., Ghazali, N. A., Tamyis, M. M., \& Ali, A. (2012). Keprihatinan guru Bahasa Melayu dalam melaksanakan kemahiran berfikir secara kritis dan kreatif. Jurnal Pendidikan Bahasa Melayu, 2(2), 19-31.

Radin Sharuddin, R. N. I., \& Mohamad, M. M. (2017). Penerapan Elemen Kemahiran Berfikir Aras Tinggi (KBAT) Dalam Mata Pelajaran Teknikal Sekolah Menengah Harian. Online Journal for TVET Practitioners, 2(1).

Ramasamy, S. (2016). Teachers' Levels of Knowledge and Interest on Higher Order Thinking Skills (HOTS) According to the Field Taught and Category of Schools. Journal of Modern Education Review, 6(9), 611-621.

Raykov, T., \& Marcoulides, G. A. (2006). A first course in structural equation modeling (2nd ed.). Lawrence Erlbaum Associates Publishers.

Salleh, M. J. (2007). Guru Efektif dan Peranan Guru dalam Mencapai Objektif Persekolahan Sekolah Rendah: Perspektif Guru Besar. 1-13.

Sang, M. S. (2011). Pendidikan di Malaysia. Kumpulan Budiman Sdn Bhd.

Saud, C. M., Mustafa, B., Mohamad Nor, F., Mohd Basri, N. F., \& Mohd Basri, N. N. (Eds.). (2017). Prosiding Persidangan Penyelidikan dan Inovasi Pendidikan Kebangsaan Kali Ke-2 2017. Institut Pendidikan Guru Malaysia. 
Schreiber, J. B., Nora, A., Stage, F. K., Barlow, E. A., \& King, J. (2006). Reporting Structural Equation Modeling and Confirmatory Factor Analysis Results: A Review. The Journal of Educational Research, 99(6), 323-338.

Schulz, H., \& Fitzpatrick, B. (2016). Teachers' Understandings of Critical and Higher Order Thinking and What This Means for Their Teaching and Assessments. Alberta Journal of Educational Research, 62(1), 61-86.

Shammugam, J. \& Sihes, A.J. (2014). Kefahaman dan pengetahuan guru dalam pentaksiran kemahiran berfikir aras tinggi (KBAT). In: 1st International Education Postgraduate Seminar: Innovation, Issues and Challenges for Educational Sustainability., 23-24 Nov, 2014, Skudai, Johor.

Shulman, L. (1987). Knowledge and Teaching:Foundations of the New Reform. Harvard Educational Review, 57(1), 1-23.

Singh, R. K. A., Singh, C. K. S., M. T. M., T., Mostafa, N. A., \& Singh, T. S. M. (2017). A Review of Research on the Use of Higher Order Thinking Skills to Teach Writing. International Journal of English Linguistics, 8(1), 86.

Tay, C. S., Faziah, H., Salbihana, S. \& Rozita, R. (2017). Penguasaan guru sekolah rendah dalam pelaksanaan pedagogi KBAT. (2017). Prosiding Persidangan Penyelidikan dan Inovasi Pendidikan Kebangsaan Kali Ke-2 2017. Institut Pendidikan Guru Malaysia.

Thomas, A., \& Thorne, G. (2009). How to Increase Higher Order Thinking. Metarie, LA: Center for Development and Learning.

Wan Ismail, W. A., Hamzah, M. I., \& Lubis, M. A. (2016). Kesediaan Guru Pendidikan Islam Sekolah Rendah di Selangor terhadap Penerapan KBAT dalam Pengajaran dan Pembelajaran. Journal of Advanced Research in Social and Behavioral Sciences, 3(1), 79-95.

Wan Jaafar, W. I. I., \& Abdul Razak, K. (2021). Pengetahuan Dan Pelaksanaan Kemahiran Berfikir Aras Tinggi Guru Pendidikan Islam Sekolah Rendah. Journal of Educational Research \& Indigenous Studies, 3(1), 185-195.

Wilson, D. M., \& Narasuman, S. (2020). Investigating Teachers' Implementation and Strategies on Higher Order Thinking Skills in School Based Assessment Instruments. Asian Journal of University Education, 16(1), 70.

Zaki, F., Ahmad, A., \& Othman, N. (2021). Kompetensi Guru dalam Penerapan Kemahiran Berfikir Aras Tinggi dalam Pengajaran Pendidikan Sejarah. Malaysian Journal of Social Sciences and Humanities (MJSSH), 6(1), 194-205.

Zainal Abidin, M. Z., \& Osman, K. (2017). Tahap pengetahuan, pemahaman, kemahiran dan pelaksaanaan guru sains terhadap kemahiran berfikir aras tinggi (KBAT). Journal of Advanced Research in Social and Behavioural Sciences, 8(1), 97-113.

Zamanzadeh, V., Ghahramanian, A., Rassouli, M., Abbaszadeh, A., Alavi-Majd, H., \& Nikanfar, A. R. (2015). Design and Implementation Content Validity Study: Development of an instrument for measuring Patient-Centered Communication. Journal of Caring Sciences, 4(2), 165-178.

Zohar, A. (1999). Teachers' metacognitive knowledge and the instruction of higher order thinking. Teaching and Teacher Education, 15(4), 413-429.

Zohar, A. (2013). Challenges in wide scale implementation efforts to foster higher order thinking (HOT) in science education across a whole school system. Thinking Skills and Creativity, 10, 233-249.

Zulkpli, Z., Mohamed, M., \& Abdullah, A. H. (2017). Assessing Mathematics Teachers' Knowledge in Teaching Thinking Skills. Sains Humanika, 9(1-4). 